\title{
A More Reliable PCR for Detection of Mycobacterium tuberculosis in Clinical Samples
}

\author{
L. F. F. KOX,${ }^{1,2^{*}}$ D. RHIENTHONG,${ }^{3}$ A. MEDO MIRANDA,${ }^{4}$ N. UDOMSANTISUK,${ }^{5}$ K. ELLIS, ${ }^{1}$ \\ J. VAN LEEUWEN, ${ }^{1}$ S. VAN HEUSDEN, ${ }^{1}$ S. KUIJPER, ${ }^{1}$ AND A. H. J. KOLK ${ }^{1}$ \\ N. H. Swellengrebel Laboratory of Tropical Hygiene, Royal Tropical Institute, ${ }^{\prime}$ and Division of Pulmonary Diseases, \\ Academic Medical Centre, ${ }^{2}$ Amsterdam, The Netherlands; Department of Microbiology, Faculty of Medicine, \\ Chulalongkorn University, ${ }^{5}$ and Tuberculosis Division ${ }^{3}$ Bangkok, Thailand; and Instituto Nacional de Saudé, \\ Dr. Ricardo Jorge, Porto, Portugal ${ }^{4}$
}

Received 20 September 1993/Returned for modification 18 October 1993/Accepted 15 December 1993

\begin{abstract}
Diagnostic techniques based on PCR have two major problems: false-positive reactions due to contamination with DNA fragments from previous PCRs (amplicons) and false-negative reactions caused by inhibitors that interfere with the PCR. We have improved our previously reported PCR based on the amplification of a fragment of the Mycobacterium tuberculosis complex-specific insertion element IS6110 with respect to both problems. False-positive reactions caused by amplicon contamination were prevented by the use of uracil- $N$ glycosylase and dUTP instead of dTTP. We selected a new set of primers outside the region spanned by the formerly used primers to avoid false-positive reactions caused by dTTP-containing amplicons still present in the laboratory. With this new primer set, 16 copies of the IS6110 insertion element, the equivalent of two bacteria, could be amplified $10^{10}$ times in 40 cycles, resulting in a mean efficiency of $77 \%$ per cycle. To detect the presence of inhibitors of the Taq polymerase, which may cause false-negative reactions, part of each sample was spiked with $M$. tuberculosis DNA. The DNA purification method using guanidinium thiocyanate and diatoms effectively removed most or all inhibitors of the PCR. However, this was not suitable for blood samples, for which we developed a proteinase $K$ treatment followed by phenol-chloroform extraction. This method permitted detection of $20 \mathrm{M}$. tuberculosis bacteria per $\mathrm{ml}$ of whole blood. Various laboratory procedures were introduced to reduce failure or inhibition of PCR and avoid DNA cross contamination. We have tested 218 different clinical specimens obtained from patients suspected of having tuberculosis. The samples included sputum $(n=145)$, tissue biopsy samples $(n=25)$, cerebrospinal fluid $(n=15)$, blood $(n=14)$, pleural fluid $(n=9)$, feces $(n=7)$, fluid from fistulae $(n=2)$, and pus from a wound $(n=1)$. The results obtained by PCR were consistent with those obtained with culture, which is the "gold standard." We demonstrate that PCR is a useful technique for the rapid diagnosis of tuberculosis at various sites.
\end{abstract}

Timely identification of infection with Mycobacterium tuberculosis is important because of the need to make decisions regarding management such as beginning antituberculosis drug therapy, isolation precautions, and prophylaxis. The outcome for the patient could be improved if fast, simple, and reliable tests could be developed. The diagnosis of extrapulmonary tuberculosis and tuberculoid meningitis is difficult, and the definitive diagnosis depends on culture of the mycobacteria, which is time-consuming and not always available.

We and others have recently reported on the use of PCR for the detection and identification of $M$. tuberculosis complex in clinical samples $(2-5,7,8,13,19,22,23,25)$. This is a rapid and sensitive technique. The exquisite sensitivity of the PCR may also be a drawback: contamination of the laboratory with amplified DNA from previous PCRs (amplicons) may cause false-positive results. In this paper, we describe the use of uracil- $N$-glycosylase (UNG) (10) and dUTP instead of dTTP to prevent false-positive results due to amplicon contamination. We have extended our work on the quality control of the performance of PCR and have developed a DNA purification method for blood and feces samples. We have used this technically improved PCR in clinical samples from patients

* Corresponding author. Mailing address: Royal Tropical Institute, N. H. Swellengrebel Laboratory of Tropical Hygiene, Meibergdreef 39 , 1105 AZ Amsterdam, The Netherlands. Phone: (0) 20-5665441. Fax: (0) 20-6971841 suspected of having tuberculosis by comparing the PCR results with the results of Ziehl-Neelsen (ZN) staining and culture.

\section{MATERIALS AND METHODS}

Bacterial strains. The same mycobacterial and nonmycobacterial strains as described previously (8) were used for the specificity testing.

Clinical samples. Sputum samples from 92 patients suspected of having tuberculosis were obtained from the Tuberculosis Division, Bangkok, Thailand. Samples were transported by air at $-20^{\circ} \mathrm{C}$. The other clinical samples were sent from various university hospitals in The Netherlands and included sputum $(n=53)$, tissue biopsy samples $(n=25)$, cerebrospinal fluid $(n=15)$, EDTA-blood $(n=14)$, pleural fluid $(n=9)$, feces $(n=7)$, fluid from fistulae $(n=2)$, and pus from a wound $(n=1)$. All samples were kept at $-20^{\circ} \mathrm{C}$.

Decontamination of sputum for culture. The sputum samples from Bangkok were decontaminated with oxalic acid. A swab was inserted into the sputum sample and then placed in $5 \%$ oxalic acid for $20 \mathrm{~min}$ at $25^{\circ} \mathrm{C}$. The swab was then incubated in $5 \% \mathrm{Na}$ citrate for $10 \mathrm{~min}$ at $25^{\circ} \mathrm{C}$.

The sputum samples from The Netherlands were decontaminated, depending on the preference of the laboratory, by the $\mathrm{NaOH}$ Petroff method $(6,15)$, by the sodium laurylsulfate method $(6,16)$, or with $\mathrm{NaOH}$-sodium citrate- $N$-acetyl-Lcysteine $(9,24)$. In all these cases, samples were concentrated by centrifugation after decontamination. 
ZN staining. At the Tuberculosis Division in Bangkok, sputum smears were microscopically examined after $\mathrm{ZN}$ staining (20). In the laboratories in The Netherlands all clinical samples were microscopically examined after $\mathrm{ZN}$ staining after being concentrated.

Routine culture. In Bangkok, sputum samples were cultured on two Löwenstein-Jensen slants. In the laboratories in The Netherlands, sputum samples were cultured on two different solid media, Löwenstein-Jensen and Colletsos or Ogawa. The samples from patients suspected of having extrapulmonary tuberculosis were cultured in addition on liquid medium, Middlebrook 7H9 broth (Difco Laboratories, Detroit, Mich.) and/or MB-Check 〈Roche〉 M, a combined liquid and three solid media (Hoffman-La Roche, Basel, Switzerland). The specimens were incubated at $37^{\circ} \mathrm{C}$ for 2 months and examined weekly for growth.

Pretreatment of clinical samples containing blood. Clinical samples which contained visible traces of blood were treated with a lysis buffer consisting of $1 \%$ Triton X-100 in $20 \mathrm{mM}$ Tris- $\mathrm{HCl}(\mathrm{pH} 8.3)$ as previously described (8).

DNA purification from clinical samples. Clinical samples (other than sputum, tissue biopsy samples, blood, and feces) and decontaminated (9) sputum pellets $(100 \mu \mathrm{l})$ were mixed with $900 \mu \mathrm{l}$ of a lysis buffer containing approximately $5 \mathrm{M}$ guanidinium thiocyanate, $1 \%$ Triton $\mathrm{X}-100,50 \mathrm{mM}$ Tris- $\mathrm{HCl}$ (pH 6.4), and $20 \mathrm{mM}$ EDTA (L6 lysis buffer [1]). DNA was purified according to the guanidinium thiocyanate method using $20 \mu \mathrm{l}$ of diatoms (1). DNA was eluted from the diatoms in two steps with 60 and $40 \mu$ l of Tris-EDTA (TE) buffer (10 mM Tris- $\mathrm{HCl}$ [pH 8.3], 1 mM EDTA).

Treatment of biopsy samples. Biopsy samples (1 to $15 \mathrm{mg}$ ) were incubated for $1 \mathrm{~h}$ at $60^{\circ} \mathrm{C}$ in a mixture of $0.1 \mathrm{mg}$ of proteinase $\mathrm{K}$ per $\mathrm{ml}, 0.5 \%$ Triton $\mathrm{X}-100$, and $20 \mathrm{mM}$ Tris- $\mathrm{HCl}$ (pH 8.3). The biopsy material was further disrupted by adding $900 \mu \mathrm{l}$ of L6 lysis buffer and $500 \mu \mathrm{l}$ of zirconium beads $(0.1-\mathrm{mm}$ diameter) (Biospec Products, Bartlesville, Okla.). The mixture was shaken in a mechanical disruptor (MiniBeadBeater model 3110; Biospec Products) for 3 min. After the zirconium beads had settled, the DNA was purified from the supernatant by the guanidinium thiocyanate method (1).

Treatment of blood and feces. Blood and feces were treated essentially as described by Meredith and coworkers (12). EDTA-blood $(600 \mu \mathrm{l})$ or feces $(600 \mu \mathrm{l})$ was mixed with $250 \mu \mathrm{l}$ of TE buffer and incubated with $100 \mu l$ of a 10-timesconcentrated stock proteinase $\mathrm{K}$ digestion buffer $(1 \mathrm{mg}$ of proteinase $\mathrm{K}$ per $\mathrm{ml}, 5 \%$ Triton $\mathrm{X}-100$, and $200 \mathrm{mM}$ Tris- $\mathrm{HCl}$ [pH 8.3]) for $1 \mathrm{~h}$ at $60^{\circ} \mathrm{C}$. DNA was isolated from the digest hy phenol-chloroform extraction. A volume of $950 \mu$ l of phenol (saturated with $100 \mathrm{mM}$ Tris- $\mathrm{HCl}$ [pH 8.3]) was added. After $10 \mathrm{~min}$ of shaking on a gyratory shaker at $100 \mathrm{rpm}$, the mixture was centrifuged for $10 \mathrm{~min}$ at $12,000 \times g$, the aqueous phase was collected, and to this 1 volume of phenol-chloroform (1:1) was added. After shaking and centrifugation as before, the aqueous phase was collected and an equal volume of chloroform was added. The aqueous phase was collected again after a further shaking and centrifugation step. DNA was precipitated by the addition of 0.05 volume of $5 \mathrm{M} \mathrm{NaCl}$ and 2 volumes of cold $100 \%$ ethanol $\left(-20^{\circ} \mathrm{C}\right)$ and then centrifuged at $12,000 \times g$ for $20 \mathrm{~min}$. The pellet was dried and dissolved in $100 \mu \mathrm{l}$ of TE buffer.

Solutions for spiking of clinical samples. For spiking and sensitivity determinations, bacteria and DNA from an $M$. tuberculosis strain that has eight copies of the insertion element IS986 (8) were used. Insertion sequence IS986 is virtually identical to the IS6110 insertion element $(11,22)$.

Precautions to prevent contamination. In our laboratory, prevention of contamination is accomplished by physical separation of different steps in the PCR procedure, using different pipettes, and wearing separate coats and gloves in each laboratory. The PCR mix is prepared in one laboratory, where work is conducted in a safety cabinet to prevent contamination of the PCR mix by shedding of material from exposed facial skin or hair. Chemicals for use in the PCR and for the treatment of clinical samples are weighed in this laboratory on a balance which is used only for this purpose. Ultrapure water (Baker, Deventer, The Netherlands) is used to make the solutions, which are sterilized in this laboratory. The solutions are stored as aliquots to minimize the number of repeated samplings. Mycobacterial strains or template DNA is not allowed in this laboratory. In a second laboratory clinical samples are treated in a safety cabinet and added to the PCR mix. If possible, we do not open more than one vial at a time in this laboratory. Only concentrations of $M$. tuberculosis DNA lower than $100 \mathrm{pg} / \mathrm{ml}$ are allowed in this room. Chemical decontamination of surfaces and equipment is done weekly in both laboratories with $0.5 \%$ sodium hypochlorite (15). The PCR and the detection of PCR products, by agarose gel electrophoresis and dot blot hybridization, are done in a third laboratory in a safety cabinet used only for this purpose.

Synthetic oligonucleotides. Lyophilized oligonucleotides were purchased from Isogen Bioscience (Amsterdam, The Netherlands). Prior to lyophilization the $A_{260}$ was determined and the oligonucleotide solution was aliquoted in 10 vials. Lyophilized oligonucleotides were kept at $-20^{\circ} \mathrm{C}$ until use.

The amount of ultrapure water needed to give a $50 \mu \mathrm{M}$ solution in a vial of lyophilized oligonucleotide was calculated by using the $A_{260}$ and the millimolar extinction coefficient of the oligonucleotide (17). The resulting solution was aliquoted in volumes of $50 \mu \mathrm{l}$ and kept at $-20^{\circ} \mathrm{C}$. One vial was kept at $4^{\circ} \mathrm{C}$ for immediate use.

PCR for clinical samples. Two oligonucleotide primers within the IS6110 insertion sequence, designated primers Pt8 (5'-GTGCGGATGGTCGCAGAGAT-3') and Pt 9 (5'CTCG ATGCCCTCACGGTTCA-3'), were used for the PCR, resulting in a 541-bp PCR fragment (10). The composition of the PCR mix was $10 \mathrm{mM}$ Tris- $\mathrm{HCl}$ (pH 8.3), $50 \mathrm{mM} \mathrm{NaCl}, 2.0 \mathrm{mM}$ $\mathrm{MgCl}_{2}, 0.01 \%$ (wt/vol) gelatin, $0.2 \mathrm{mM}$ (each) deoxynucleoside triphosphates (dATP, dCTP, dGTP, and dUTP), $0.2 \mu \mathrm{M}$ (each) primers Pt8 and Pt9, 1 U of Taq polymerase (PerkinElmer Cetus, Norwalk, Conn.), and 0.01 U of UNG, (GIBCO BRL, Gaithersburg, Md.) per 50- $\mu$ l reaction volume. The PCR mix was aliquoted in a final volume of $40 \mu$ l per reaction vial and stored at $-20^{\circ} \mathrm{C}$. When a test was performed, the reaction vials were removed from the freezer and $50 \mu \mathrm{l}$ of mineral oil (Sigma, St. Louis, Mo.) was added to each vial before the $10-\mu l$ sample was placed under the oil layer. For preparing the PCR mixes and pipetting the mineral oil, positive displacement pipette tips (Microman, Gilson, France) were used. For pipetting clinical samples and DNA solutions, we used DNA-PCR filter tips (Greiner, Nürtingen, Germany). PCR was performed in a water bath thermocycler (Bio-med 60 processor; Bio-med, Theres, Germany) or a heating block thermocycler (Gene ATAQ Controller; Pharmacia LKB, Uppsala, Sweden). The temperature indicators of the thermocyclers were checked monthly with an electrical thermometer $(51 \mathrm{~K} /$ Thermometer; Fluke, Everett, Wash.), which in turn was checked twice a year against an officially calibrated mercury thermometer. The PCR incubations were as follows: $5 \mathrm{~min}$ at $50^{\circ} \mathrm{C}$ to allow breakdown of amplicons by UNG, followed by 40 cycles of $1.5 \mathrm{~min}$ of denaturation at $94^{\circ} \mathrm{C}, 2 \mathrm{~min}$ of annealing at $65^{\circ} \mathrm{C}$, and $3 \mathrm{~min}$ of primer extension at $72^{\circ} \mathrm{C}$. If the $\mathrm{PCR}$ products were not 
analyzed directly after the final cycle, the vials were incubated for a minimum of $1 \mathrm{~h}$ at $72^{\circ} \mathrm{C}$.

The quality of the PCR mix was tested by amplification of a series of 1,000,100, 10 and $1 \mathrm{fg}$ of $M$. tuberculosis DNA per vial. Ten microliters of TE buffer was tested in duplicate to provide a negative control for contamination with $M$. tuberculosis DNA during the preparation of the mix. To control for the activity of the UNG, a vial with $10 \mu \mathrm{l}$ of a $15-\mathrm{pg} / \mu \mathrm{l}$ 541-bp amplicon solution was amplified in the same assay. This amplicon solution was prepared by using $1,000 \mathrm{fg}$ of $M$. tuberculosis DNA as a template in PCR and subsequently diluting this PCR product 1,000-fold. The PCR mix was considered to be of sufficient quality if $10 \mathrm{fg}$ of $M$. tuberculosis DNA, corresponding to two bacteria, could be detected and if the vials containing TE buffer and the vial containing $150 \mathrm{pg}$ of 541-bp amplicon were negative in PCR.

In all PCR series involving clinical samples, positive controls consisting of a series of vials containing $1,000,100,10$, and $1 \mathrm{fg}$ of $M$. tuberculosis DNA and two vials with TE buffer were included. Each treated sample from a patient was tested in triplicate. One part $(10 \mu \mathrm{l})$ was spiked with $10 \mathrm{fg}$ of $M$. tuberculosis DNA, and two parts were not spiked. If all three samples were positive, then the sample was considered positive. The sample was scored as negative if the nonspiked reactions were negative and the spiked reaction was positive. If the results for the nonspiked reactions were ambiguous, the PCR was repeated. If all three reactions were negative, then there were inhibitors in the sample. In such a case, the PCR was repeated with a smaller sample volume; if inhibition recurred, another DNA extraction method was used; if there was still inhibition, then a further sample from the patient was requested.

Detection of amplified DNA. The PCR products were analyzed by agarose gel electrophoresis on $2 \%$ agarose gels (8). The results were recorded by Bio-print photodocumentation and when necessary stored in the image storage system (Vilber-Lourmat, Marne-la-Vallée, France).

For comparison of PCR results, the intensity of the PCR products was compared visually with the intensity of the PCR products of the positive controls. An intensity equal to or greater than that of the product of $100 \mathrm{fg}$ of $M$. tuberculosis DNA was scored $2+$, an intensity between those of the products of 100 and $10 \mathrm{fg}$ of $M$. tuberculosis DNA was scored + , and an intensity less than that of $10 \mathrm{fg}$ of $M$. tuberculosis DNA was scored + . For efficiency calculations, the amount of PCR product was more accurately determined by spot quantification, by interpolation with a standard curve using the Bio-profile software (Vilber-Lourmat). The standard curve was constructed employing the amounts of DNA from the fragments of the HaeIII-digested $\phi X 174$ replicative form molecular size marker (New England Biolabs, Beverly, Md.).

The PCR results with clinical samples were confirmed by dot blot hybridization with a biotin-labeled oligonucleotide probe.

Oligonucleotide labeling with biotin. The oligonucleotide Pt10 (5'-AGCACGATTCGGAGTGGGCA-3'), which is situated within the 541-bp fragment and corresponds to bp 134 to 153 of the insertion sequence IS6110 of M. tuberculosis, was tail labeled at the $3^{\prime}$ end of the DNA with biotin-16-dUTP by using the enzyme terminal transferase (18). Biotin-labeled Pt10 was also commercially obtained (Isogen Bioscience). The biotin group was covalently attached to the $5^{\prime}$ end of the DNA via a six-carbon spacer arm.

Dot blot hybridization and colorimetric detection. Reinforced nitrocellulose membranes (Duralose; Stratagene, La Jolla, Calif.) were cut into pieces ( 8 by $12 \mathrm{~cm}$ ) and presoaked in water and then in $10 \times \mathrm{SSC}(1 \times \mathrm{SSC}$ is $0.15 \mathrm{M} \mathrm{NaCl}$ plus
TABLE 1. Efficiency of PCR

\begin{tabular}{rrrrrr}
\hline \multicolumn{2}{c}{ Template DNA } & & \multicolumn{2}{c}{ PCR product } & \\
\cline { 1 - 2 } \cline { 5 - 6 } $\begin{array}{c}\text { Amt } \\
\text { (fg) }\end{array}$ & $\begin{array}{c}\text { No. of copies } \\
\text { of IS6110 }\end{array}$ & Amt (ng) & $\begin{array}{c}\text { No. of molecules of } \\
541 \text {-bp amplicon } \\
\left(10^{11}\right)\end{array}$ & Efficiency \\
\hline 10,000 & 16,000 & & $758 \pm 93$ & 13 & \\
1,000 & 1,600 & & $426 \pm 68$ & 7.2 & 0.58 \\
100 & 160 & & $197 \pm 50$ & 3.3 & 0.65 \\
10 & 16 & $81 \pm 65$ & 1.4 & 0.71 \\
\hline
\end{tabular}

$0.015 \mathrm{M} \mathrm{Na}$-citrate [pH 7.0]). Samples of $5 \mu$ l of PCRamplified DNA were made up to a final volume of $50 \mu \mathrm{l}$ in water and denatured by boiling for $5 \mathrm{~min}$ and subsequent cooling on ice. After the addition of $50 \mu \mathrm{l}$ of an ice-cold solution of $20 \times \mathrm{SSC}$, the mixtures were spotted onto a presoaked Duralose (Stratagene) membrane by using a dot blot apparatus (Schleicher-Schüll, Dassel, Germany), and a vacuum of $60 \mathrm{~cm} \mathrm{Hg}$ (ca. $800 \mathrm{kPa}$ ) was applied. The spots were washed with $200 \mu \mathrm{l}$ of $10 \times \mathrm{SSC}$. The DNA was fixed to the membranes by UV $(312 \mathrm{~nm})$ cross-linking at $1 / \mathrm{cm}^{2}$ (Fluo-link TFL20M; Vilber-Lourmat) or by heating at $120^{\circ} \mathrm{C}$ for $15 \mathrm{~min}$. The membranes were sealed in a plastic bag with $5 \mathrm{ml}$ of $5 \times$ SSC-1\% (wt/vol) blocking agent (Boehringer, Mannheim, Germany) $-0.1 \%$ (wt/vol) $N$-laurylsarcosine- $0.02 \%$ (wt/vol) sodium dodecyl sulfate (SDS) and prehybridized at $50^{\circ} \mathrm{C}$ for 15 min. After the addition of 1 pmol of biotin-labeled Pt10 from either source to the prehybridization mix, the membranes were incubated at $50^{\circ} \mathrm{C}$ for another $2 \mathrm{~h}$. The membranes were washed twice at $50^{\circ} \mathrm{C}$ for $5 \mathrm{~min}$ in $50 \mathrm{ml}$ of $2 \times \mathrm{SSC}-0.1 \%$ (wt/vol) SDS. The membranes were used directly for the detection of the hybridized probe by incubation with streptavidin-alkaline phosphatase conjugate according to the instructions of the manufacturer (Boehringer) and scored visually (8).

\section{RESULTS}

Specificity, sensitivity, and efficiency of the PCR. PCR using the primers Pt8 and Pt9 was specific for the M. tuberculosis complex. No PCR products were found with bacteria or mycobacteria other than those belonging to this complex. To determine the sensitivity of the PCR, eight series of $10^{4}, 10^{3}$, $10^{2}, 10$, and $1 \mathrm{fg}$ of $M$. tuberculosis DNA were amplified. In all eight tests $10 \mathrm{fg}$ of DNA, the DNA equivalent of two bacteria or 16 copies of the IS6110 insertion element, could be detected by agarose gel electrophoresis. PCRs with $1 \mathrm{fg}$ of DNA were positive in two of the eight tests.

The amount of PCR product resulting from the different amounts of template DNA was determined by using the Bio-profile software (Table 1). The efficiency of the PCR amplification was calculated by using the following formula: (1 $+x)^{n}=y$, where $\mathrm{x}$ is the mean efficiency of a cycle, $n$ is the number of cycles, and $y$ is the amplification factor after $n$ cycles. The amount of template DNA and amplicon is expressed as the number of copies of the IS6110 insertion element. Amplification of $10^{4}, 10^{3}, 10^{2}$, and $10 \mathrm{fg}$ of $M$. tuberculosis DNA in 40 PCR cycles resulted in mean efficiencies of, respectively, $58,65,71$, and $77 \%$ per cycle. Large quantities of DNA are amplified less efficiently than small amounts of DNA because the plateau effect occurs earlier for larger amounts of template DNA.

Detection of amplified DNA. The results obtained by agarose gel electrophoresis were confirmed by dot blot hybridization using the enzymatically biotin-labeled probe Pt10. The results 
$\begin{array}{llllllllllllll}1 & 2 & 3 & 4 & 5 & 6 & 7 & 8 & 9 & 10 & 11 & 12 & 13 & 14\end{array}$

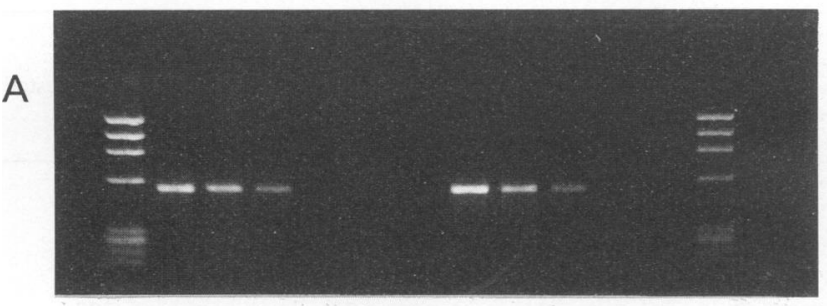

B

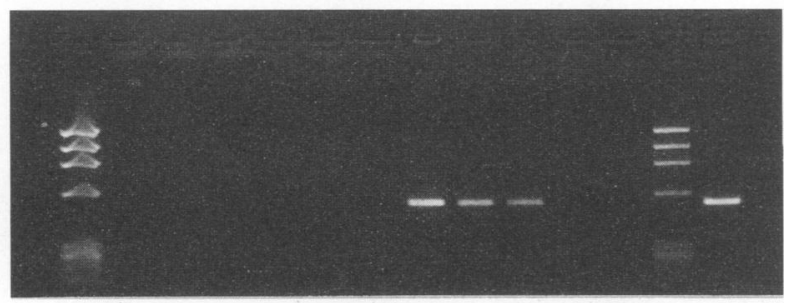

C

FIG. 1. Ability of UNG to break down dUTP-containing amplicons without changing the efficiency of PCR. dUTP-containing amplicons and $M$. tuberculosis DNA were used as template in PCR in the absence (A) and presence (B and C) of $0.01 \mathrm{U}$ of UNG. Lanes 2 to $6,10^{3}, 10^{6}$, $10^{9}, 10^{12}$, and $10^{15}$-times-diluted 15 -ng/ $\mu$ l amplicon solution; lanes 8 to $11,1,000,100,10$, and $1 \mathrm{fg}$ of $M$. tuberculosis DNA; lanes 7 and 12, TE controls; lanes 1 and 13, respectively, 800 and $400 \mathrm{ng}$ of HaeIIIdigested $\phi$ X174 DNA (replicative form) as a molecular size marker; lane 14, 541-bp fragment as a molecular size marker. Amplification products were detected by agarose gel electrophoresis (A and B) or by dot blot hybridization (C).

with this oligonucleotide were similar to those with the 188-bp digoxigenin-labeled fragment, which we used previously (8). With both probes $100 \mathrm{pg}$ of PCR product could be detected. Similar results were obtained with the chemically biotinlabeled Pt10 probe (data not shown). The oligonucleotide probe has the advantage that the hybridization time can be reduced from the $16 \mathrm{~h}$ required for the 188-bp probe to $2 \mathrm{~h}$.

Pre-PCR amplicon degradation. The most likely cause of false-positive PCR results is contamination with amplicons from previous PCRs. After using the primer set INS1 and INS2 for a year, we noticed 245-bp amplicons in negative controls. Contamination was due to the presence of amplicons, not $M$. tuberculosis complex bacteria or DNA (8). We replaced the primers INS1 and INS2 with Pt8 and Pt9, and we used dUTP instead of dTTP to make amplicons degradable by UNG. These maneuvers did not affect the overall efficiency of our PCR (data not shown).

To demonstrate the gravity of amplicon contamination we tested $10 \mu \mathrm{l}$ of 1,000-fold serial dilutions of a $15-\mathrm{ng} / \mu \mathrm{l}$ 541-bp amplicon solution in PCR (Fig. 1A). This amplicon solution was prepared by using $1,000 \mathrm{fg}$ of $M$. tuberculosis DNA as a template in a PCR. We chose to start with a 1,000 -fold dilution since $10 \mu \mathrm{l}$ of a 100-fold dilution of the 541-bp amplicon solution could contain enough template DNA ( $2 \mathrm{fg})$ to give a positive reaction in PCR, due to the amplification of $M$. tuberculosis DNA. Figure 1A shows that $10 \mu \mathrm{l}$ of a $15-\mathrm{ng} / \mu \mathrm{l}$ amplicon solution can still be amplified in PCR, even following a $10^{9}$-fold dilution. This solution contains $0.15 \mathrm{fg}$ of amplicon.

The minimal amount of UNG necessary to break down contaminating amplicons was investigated by amplification of $10 \mu \mathrm{l}$ of the amplicon dilutions mentioned above in the presence of $0.5,0.2,0.1,0.05$, and $0.01 \mathrm{U}$ of UNG. Panels B and $C$ of Fig. 1 show that $0.01 \mathrm{U}$ of UNG was able to break down $150 \mathrm{pg}$ of 541-bp amplicons. The use of UNG did not affect the sensitivity of the PCR, as shown in Fig. 1A and B where the amplicon bands in lanes 8,9 , and 10 are of equal intensity. We performed PCR with 1,000, 100, 10, and $1 \mathrm{fg}$ of $M$. tuberculosis DNA in the absence and presence of UNG. The same sensitivity was seen in both PCRs.

Stability of the PCR mix. For routine diagnosis it is necessary to prepare a batch of ready-for-use PCR vials and to test the quality of the batch before using it for clinical samples. We found it convenient to make batches of 200 vials. We consider the batch of sufficient quality if $10 \mathrm{fg}$ of $M$. tuberculosis DNA can be amplified, resulting in a visible band in agarose gel electrophoresis, if $150 \mathrm{pg}$ of 541-bp amplicon can be degraded, and if TE controls are negative.

We tested the stability of the PCR mix at different temperatures. We kept mixes at -20 or $+4^{\circ} \mathrm{C}$ for 12 weeks, 18 or $37^{\circ} \mathrm{C}$ for up to 1 week and performed a PCR with $1,000,100$, and 10 fg of $M$. tuberculosis DNA. The quality of PCR mixes that had been stored for 12 weeks at $-20^{\circ} \mathrm{C}$ was the same as that of freshly prepared mixes. PCR mixes were stable at $4^{\circ} \mathrm{C}$ for 1 week, after which the quality of the mix decreased: $10 \mathrm{fg}$ of $M$. tuberculosis DNA could not be detected. The stability of the PCR mixes stored at $20^{\circ} \mathrm{C}$ (room temperature) and $37^{\circ} \mathrm{C}$ deteriorated within $24 \mathrm{~h}$ (results not shown). These experiments show that mixes can be stored for at least 3 months in the freezer and up to 1 week on ice.

The effect of repeated thawing and freezing on the stability of the PCR mix was also tested. Thawing occurred at room temperature over $30 \mathrm{~min}$, during which time the contents of the vial were at $20^{\circ} \mathrm{C}$ for about $10 \mathrm{~min}$. After three cycles of thawing and freezing, the quality of the mix was unaffected, but it deteriorated after four or more cycles (results not shown). This means that an accidental thawing is not harmful for the PCR mix.

Sensitivity of PCR for clinical samples. To determine the detection limit of the PCR in clinical samples, we divided samples into four portions and spiked three portions with different amounts of $M$. tuberculosis bacteria $(1,000,100$, and 10 per portion) before sample treatment. Our samples were four sputum samples ( $1 \mathrm{ml}$ per portion), one liver biopsy sample (10 mg per portion), and one feces sample $(600 \mu \mathrm{l}$ per portion) from patients suffering from diseases other than tuberculosis and one blood sample $(600 \mu \mathrm{l}$ per portion) from a healthy individual. PCRs were performed with $10-\mu$ l portions (1/10 of the volume) of the treated sample. To detect the presence of inhibitors, $10 \mu \mathrm{l}$ of the treated nonspiked sample was tested in the presence of $10 \mathrm{fg}$ of $M$. tuberculosis DNA. In all cases the spiked DNA could be detected, indicating that PCR was not inhibited. In the liver biopsy sample, feces, and two sputum samples the detection limit was $10 \mathrm{M}$. tuberculosis bacteria per reaction vial. In the other two sputum samples and the blood the detection limit was one bacterium per reaction vial (results not shown).

PCR results compared with those of culture and $\mathrm{ZN}$ staining. Culture provides the "gold standard" for the diagnosis of infections with $M$. tuberculosis. We have tested 218 clinical specimens from patients suspected of having tuberculosis. 
TABLE 2. Comparison of the PCR results of clinical samples from patients suspected of tuberculosis with results of culture and $\mathrm{ZN}$ staining ${ }^{a}$

\begin{tabular}{|c|c|c|c|c|c|c|}
\hline \multirow{3}{*}{ Sample source(s) } & \multirow{3}{*}{ PCR result } & \multicolumn{4}{|c|}{ No. of samples with indicated culture result } & \multirow{3}{*}{ Total no. tested } \\
\hline & & \multicolumn{2}{|c|}{ Positive } & \multicolumn{2}{|c|}{ Negative } & \\
\hline & & $\mathrm{ZN}+$ & $\mathrm{ZN}-$ & $\mathrm{ZN}+$ & $\mathrm{ZN}-$ & \\
\hline \multicolumn{7}{|l|}{ Sputum from: } \\
\hline \multirow[t]{2}{*}{ Thailand } & Positive & 35 & 12 & 2 & 12 & 61 \\
\hline & Negative & $5^{b}$ & 0 & 0 & 20 & 25 \\
\hline \multirow[t]{2}{*}{ The Netherlands } & Positive & 26 & 2 & 1 & 1 & 30 \\
\hline & Negative & $3^{c}$ & 0 & () & 20 & 23 \\
\hline \multirow[t]{2}{*}{ Cerebrospinal fluid } & Positive & 1 & 1 & () & 1 & 3 \\
\hline & Negative & 0 & 0 & 0 & 12 & 12 \\
\hline \multirow[t]{2}{*}{ Pleural fluid, fistula fluid, pus } & Positive & 1 & 2 & () & 0 & 3 \\
\hline & Negative & $1^{d}$ & 0 & 0 & 11 & 12 \\
\hline \multirow[t]{2}{*}{ Biopsy } & Positive & 2 & 1 & 2 & 1 & 6 \\
\hline & Negative & $3^{c}$ & 0 & 0 & 15 & 18 \\
\hline \multirow[t]{2}{*}{ Blood } & Positive & 0 & 0 & 0 & 1 & 1 \\
\hline & Negative & 0 & 0 & 0 & 13 & 13 \\
\hline \multirow[t]{2}{*}{ Feces } & Positive & 0 & 0 & 0 & 0 & 0 \\
\hline & Negative & 0 & 0 & 0 & 6 & 6 \\
\hline
\end{tabular}

"Six sputum samples from Thailand, one biopsy sample, and one feces sample contained inhibiting components.

"One Mycobacterium fortuitum, one Mycobacterium chelonae, and three unidentified mycobacterial strains were cultured.

c One Mycobacterium avium and two unidentified mycobacterial strains were cultured.

"Mycobacterium gordonae was cultured.

"M. avium was cultured in all cases.

Specimens were obtained from a wide variety of sites, and the results are shown in Table 2 . One sputum sample from a patient from The Netherlands was positive by PCR but negative by $\mathrm{ZN}$ staining and culture. Since bronchoalveolar lavage fluid obtained from this patient was positive both by $\mathrm{ZN}$ staining and by culture, it is highly probable that the patient had tuberculosis. The clinical samples other than sputa were obtained from patients suspected of having tuberculosis who had a variety of underlying conditions such as other lung diseases, AIDS, or cancer. When the PCR result was positive and the results of $\mathrm{ZN}$ staining and/or culture were negative, the clinical picture corroborated the PCR results and the patients responded to treatment for tuberculosis.

\section{DISCUSSION}

Amplicon contamination. False-positive reactions are a major problem with PCR methods for the detection of the $M$. tuberculosis complex. After using the primer set INS1 and INS2 for 1 year, we noticed that negative controls were positive in PCR, because of the presence of amplicons in the reaction vial (8). PCR with $10 \mu \mathrm{l}$ of a $10^{9}$-times-diluted 15 -ng/ $\mu$ l 541-bp amplicon solution, which is about $0.15 \mathrm{fg}$ or 250 amplicon molecules, still gives a clearly visible band in an agarose gel. This means that an aerosol droplet of this solution with a volume of $10^{-6} \mu \mathrm{l}$ can be diluted at least 100 times and can still cause a false-positive reaction. To prevent amplicon contamination, we replaced the primers INS1 and INS2 with Pt8 and PT9 and simultaneously introduced the use of dUTP instead of dTTP to make the amplicons degradable by UNG (10). Neither of these measures affected the efficiency of the PCR. The use of $0.01 \mathrm{U}$ of UNG was sufficient to break down $150 \mathrm{pg}$ of 541-bp amplicon, which is more than enough since this is about $10^{6}$ times more than the amount of amplicon needed in PCR to get an intensity comparable to that of a false-positive negative control when UNG is omitted in the PCR mix.

During a training course five scientists were instructed in the technique of PCR for $M$. tuberculosis and the measures needed to avoid contamination. They were asked to perform PCRs without UNG (but with dUTP instead of dTTP), and already after the second PCR two had false-positive results. Thus, the amplicons may be spread by the operator despite these precautions. These findings show that false-positive reactions due to the spread of $M$. tuberculosis DNA can also be caused by the investigator. This poses a serious problem and suggests that stringent attention to matters of detail is necessary to prevent contamination with amplicons or DNA carried by laboratory workers and that workers in PCR should not combine their work with isolation of $M$. tuberculosis DNA nor with restriction fragment length polymorphism analysis.

An alternative to the pre-PCR enzymatic amplicon degradation method is the post-PCR photochemical method. We prefer the former since the large concentrations of isopsoralen that are needed in the post-PCR photochemical method for inactivation of small and GC-rich amplicons can reduce the activity of Taq polymerase (14); moreover, the isopsoralen is mutagenic.

Inhibition. To detect false-negative reactions due to the presence of substances that inhibit Taq polymerase, we tested clinical samples in PCR in the presence of $10 \mathrm{fg}$ of $M$. tuberculosis DNA. This approach gives one semiquantitative datum regarding the amount of $M$. tuberculosis in the clinical sample by comparison with a series of amplified $M$. tuberculosis DNA. Quantitation of the number of $M$. tuberculosis bacteria in the clinical sample can be relevant for follow-up of patients on drug therapy to detect drug resistance at an early stage. Inhibition was demonstrated in six sputum samples from Thailand. We are investigating whether the inhibition is caused by the storage vials, the transport of the samples, or storage at $-20^{\circ} \mathrm{C}$, since the sputum samples from the hospitals in The Netherlands, which were usually tested while fresh, did not show inhibition of the PCR.

Treatment of clinical samples. Most or all of the inhibiting substances in clinical samples are effectively removed by the DNA purification method with guanidinium thiocyanate and diatoms (1). This method is also applicable to lymphocyte fractions from blood but not to whole blood, since hemoglobin will inhibit the PCRs. The isolation of the lymphocyte fraction must be done with a sample less than $24 \mathrm{~h}$ old. Blood which is 
older or is frozen cannot be used because of the lysis of erythrocytes which releases hemoglobin. The method of choice for isolation of DNA from blood is proteinase $\mathrm{K}$ treatment followed by phenol-chloroform extraction, since this method gives good results, is simple, and can also be used on frozen blood samples. A further advantage of this DNA isolation procedure over the method using guanidinium thiocyanate and diatoms is that larger volumes of blood can be used, improving the chances of detection of infection, since the DNA binding capacity of diatoms is limiting. We also used proteinase $\mathrm{K}$ treatment followed by phenol-chloroform extraction on feces, since this method proved to be superior to the guanidinium thiocyanate method. One of seven feces samples still interfered in the PCR.

PCR results with clinical samples. The results with PCR accorded well with the bacteriological data, except for Thai sputa which were negative by $\mathrm{ZN}$ staining and culture. At the Tuberculosis Division in Bangkok, ZN staining and culture were done without concentrating the sample during sputum decontamination, leading to a lower sensitivity. This was probably the reason for the high number (12 of 32) of sputum samples that were positive by PCR but negative by ZN staining and culture. The PCR results corresponded well with the culture results, except for one cerebrospinal fluid sample, one tissue biopsy sample, and one blood sample that were positive in PCR but negative in $\mathrm{ZN}$ staining and culture. These samples were obtained from patients for whom clinical data supported the diagnosis of tuberculosis and who responded to treatment for tuberculosis. The data suggest that PCR can be a useful tool for the diagnosis of extrapulmonary tuberculosis.

Mycobacteria other than tuberculosis. The increased incidence of mycobacterial infections other than tuberculosis emphasizes the need for correct species identification. Twelve samples $(6 \%)$ contained mycobacteria other than tuberculosis (Table 2). None of these samples were positive in the PCR for $M$. tuberculosis complex, which demonstrates the specificity of our PCR.

Recommendations. In conclusion, PCR is the method of choice for the diagnosis of tuberculosis in cases where the suspicion is high but $\mathrm{ZN}$ staining is negative. When the sample is positive in $\mathrm{ZN}$ staining, PCR permits distinction between $M$. tuberculosis complex and other mycobacterial infections. In comparison with our previously described PCR for the detection of $M$. tuberculosis complex (8), the approach described here has the following advantages: (i) the risk of amplicon contamination is removed by the use of UNG and the incorporation of dUTP instead dTTP, thereby reducing falsepositive reactions, resulting in increased specificity of the PCR for clinical samples; (ii) costs are lower since fewer reactions are needed to test one sample, the chemically biotin-labeled probe is cheaper than the digoxigenin labeled probe (8), and the hybridization process takes only $2 \mathrm{~h}$; (iii) by conducting quality control of the PCR procedure and apparatus, the number of failures is reduced; and (iv) contamination with DNA is reduced by limiting the amount of DNA in the sample preparation room. The detection limit for $M$. tuberculosis bacteria in clinical samples has been improved 10 -fold by concentrating the samples by centrifugation whenever possible. Stringent attention to matters of detail is necessary to prevent contamination by DNA carried by laboratory workers.

Quality control of the PCR mix and the performance of the amplification itself is mandatory if routine PCR is to replace culture for the diagnosis of tuberculosis.

\section{ACKNOWLEDGMENTS}

L.F.F.K. was supported by a grant from the Amsterdam Society and Research Fund for Prevention and Cure of Tuberculosis. This study was supported by the commission of the European Communities Directorate for Science and Development (project number TS3-CT910036) and the WHO Programme for Vaccine Development and Tuberculosis Programme.

We thank W. J. Terpstra and H. M. Jansen for their continuing support during this investigation and E. M. Rankin for critical review of the manuscript.

\section{REFERENCES}

1. Boom, R., C.-A. Sol, M. M. M. Salimans, C. L. Jansen, P. M. E. Wertheim van Dillen, and J. van der Noordaa. 1990. Rapid and simple method for purification of nucleic acids. J. Clin. Microbiol. 28:495-503.

2. Brisson-Noël, A., C. Aznar, C. Chureau, S. Nguyen, C. Pierre, M. Bartoli, R. Bonete, G. Pialoux, B. Gicquel, and G. Garrigue. 1991. Diagnosis of tuberculosis by DNA amplification in clinical practice evaluation. Lancet 338:364-366.

3. Brisson-Noël, A., B. Gicquel, D. Lecossier, V. Lévy-Frébault, X. Nassif, and A. J. Hance. 1989. Rapid diagnosis of tuberculosis by amplification of mycobacterial DNA in clinical samples. Lancet ii: $1069-1071$.

4. Cousins, D. V., S. D. Wilton, B. R. Francis, and B. L. Gow. 1993. Use of polymerase chain reaction for rapid diagnosis of tuberculosis. J. Clin. Microbiol. 30:255-258.

5. Eisenach, K. D., M. D. Sifford, M. D. Cave, J. H. Bates, and J. T. Crawford. 1991. Detection of Mycobacterium tuberculosis in sputum samples using a polymerase chain reaction. Am. Rev. Respir. Dis. 144:1160-1163.

6. Groothuis, D. G., and M. Yates. 1991. Diagnostic and public health mycobacteriology. Prepared for the European Society for Mycobacteriology by an ad hoc committee. Bureau of Hygiene and Tropical Disease, London.

7. Hermans, P. W. M., A. R. J. Schuitema, D. van Soolingen, C. P. H. J. Verstijnen, E. M. Bik, J. E. R. Thole, A. H. J. Kolk, and J. D. A. van Embden. 1990. Specific detection of Mycobacterium tuberculosis complex strains by polymerase chain reaction. J. Clin. Microbiol. 28:1204-1213.

8. Kolk, A. H. J., A. R. J. Schuitema, S. Kuijper, J. van Leeuwen, P. W. M. Hermans, J. D. A. van Embden, and R. A. Hartskeerl. 1992. Detection of Mycobacterium tuberculosis in clinical samples by using polymerase chain reaction and a nonradioactive detection system. J. Clin. Microbiol. 30:2567-2575.

9. Kubica, G. P., W. E. Dye, M. L. Cohn, and G. Middlebrook. 1963. Sputum digestion and decontamination with N-acetyl-L-cysteinesodium hydroxide for culture of mycobacteria. Am. Rev. Respir. Dis. 87:775-779.

10. Longo, M. C., M. S. Berninger, and J. L. Hartley. 1990. Use of uracil DNA glycosylase to control carry-over contamination in polymerase chain reactions. Gene 93:125-128.

11. McAdam, R. A., P. W. M. Hermans, D. van Soolingen, Z. F. Zainuddin, D. Catty, J. D. A. van Embden, and J. W. Dale. 1990. Characterization of a Mycobacterium tuberculosis insertion sequence belonging to the IS3 family. Mol. Microbiol. 4:1607-1613.

12. Meredith, S. E. O., E. E. Zijlstra, G. J. Schoone, C. C. M. Kroon, G. J. J. M. van Eys, K. U. Schaeffer, and A. M. El-Hassan. Development and application of the polymerase chain reaction for the detection and identification of Leishmania parasites in clinical material. Arch. Inst. Pasteur (Tunis), in press.

13. Pao, C. C., T. S. Benedict Yen, J. B. You, J. S. Maa, E. H. Fiss, and C. H. Chang. 1990. Detection and identification of Mycobacterium tuberculosis by DNA amplification. J. Clin. Microbiol. 28:18771880.

14. Persing, D. H. 1991. Polymerase chain reaction: trenches to benches. J. Clin. Microbiol. 29:1281-1285.

15. Prince, A. M., and L. Andrus. 1992. PCR: how to kill unwanted DNA. BioTechniques 12:358-360.

16. Rüsch-Gerdes, S., K.-H. Schröder, and M. Pfohl. 1988. Untersuchung met dem System Bactec 460 3. Isolierung von Mycobacte- 
rium tuberculosis aus Sputum. Vergleich der radiometrischen mit der konventionellen Methode nach Pankreatin-Desogen-, Laurylsulfat- und N-Acetyl-L-Cystein-NaOH-Vorbehandlung. Prax. Klin. Pneumol. 42:172-174.

17. Sambrook, J., E. F. Fritsch, and T. Maniatis. 1989. Molecular cloning: a laboratory manual, 2nd ed., p. 11-21. Cold Spring Harbor Laboratory, Cold Spring Harbor, N.Y.

18. Schmitz, G. G., T. Walter, R. Seibl, and C. Kessler. 1990 Nonradioactive labeling of oligonucleotides in vitro with the hapten digoxigenin by tailing with terminal transferase. Anal Biochem. 192:222-231.

19. Shawar, R. M., F. A. K. El-Zaatari, A. Nataraj, and J. E. Clarridge. 1993. Detection of Mycobacterium tuberculosis in clinical samples by two-step polymerase chain reaction and nonisotopic hybridization methods. J. Clin. Microbiol. 31:61-65.

20. Smithwick, R. W. 1976. Laboratory manual for acid-fast microscopy, 2nd ed. Center for Disease Control, Atlanta.

21. Sritharan, V., and R. H. Barker, Jr. 1991. A simple method for diagnosing $M$. tuberculosis infection in clinical samples using PCR. Mol. Cell. Probes 5:385-395.

22. Thierry, D., A. Brisson-Noël, V. Vincent-Lévy-Frébault, S. Nguyen, J. L. Guesdon, and B. Gicquel. 1990. Characterization of a Mycobacterium tuberculosis insertion sequence, IS6110, and its application in diagnosis. J. Clin. Microbiol. 28:2668-2673.

23. Thierry, D., M. D. Cave, K. D. Eisenach, J. T. Crawford, J. H. Bates, B. Gicquel, and J. L. Guesdon. 1990. IS6110, an IS-like element of Mycobacterium tuberculosis complex. Nucleic Acids Res. 18:188.

24. Vestal, A. L. 1977. Procedures for the isolation and identification of mycobacteria. U.S. Department of Health, Education, and Welfare publication no. CDC 77-8230. Center for Disease Control, Atlanta.

25. Wilson, S. M., R. McNerney, P. M. Nye, P. D. Godfrey-Faussett, N. G. Stoker, and A. Voller. 1993. Progress toward a simplified polymerase chain reaction and its application to diagnosis of tuberculosis. J. Clin. Microbiol. 31:776-782. 